\title{
FUNGSI PEMERINTAH DAERAH DALAM PENGELOLAAN PERTAMBANGAN DI KABUPATEN TRENGGALEK TAHUN 2015
}

\section{The Function Of Local Government In The Management Of Minning In District Trenggalek In 2015}

\author{
Yustafa Badrus Su'adah ${ }^{1}$ \\ ${ }^{1}$ Magister Ilmu Administrasi Universitas Kadiri
}

\begin{abstract}
Abstrak
Salah satu kegiatan usaha yang menunjang pembangunan di Indonesia adalah sektor pertambangan. Usaha pertambangan merupakan kegiatan untuk mengoptimalkan pemanfaatan sumber daya alam tambang atau bahan galian yang terdapat dalam bumi Indonesia. Pertambangan adalah sebagian atau seluruh tahapan kegiatan dalam rangka penelitian, pengelolaan dan pengusahaan mineral atau batubara yang meliputi penyelidikan umum, eksplorasi, studi kelayakan, konstruksi, penambangan, pengolahan dan pemurnian, pengangkutan dan penjualan, serta kegiatan pasca tambang.
\end{abstract}

Kata Kunci: izin pertambangan lokal; izin pertambangan kabupaten trenggalek; kegiatan usaha pertambangan

\section{Abstract}

One of the business activities that support development in Indonesia is the mining sector. The mining business is an activity to optimize the utilization of natural resources of mining or excavation material on land. Mining is part or all of the phases of operations in the research, management, and exploitation of minerals or coal covering general investigation, exploration, feasibility study, construction, mining, processing and refining, transportation and sales, and post-mining activities.

Keywords: local mining permit; trenggalek regency mining permit; mining business activity

\section{A. PENDAHULUAN}

Kegiatan pembangunan pada hakekatnya adalah kegiatan manusia dalam menggali dan mengolah sumber daya alam dengan sebaikbaiknya yang meliputi air, udara, tanah dan kekayaan alam yang terkandung didalamnya. Menurut Pasal 33 ayat (3) Undang-Undang Dasar Negara Republik Indonesia Tahun 1945 yang berbunyi "bumi dan air dan kekayaan alam yang terkandung didalamnya dikuasai oleh negara dan dipergunakan untuk sebesar-besarnya untuk kemakmuran rakyat". Bahan tambang termasuk didalamnya, dikuasai oleh negara. Untuk tercapainya kesejahteraan dan kemakmuran rakyat Indonesia maka diselenggarakan berbagai macam kegiatan usaha dan produksi yang menunjang pembangunan. Salah satu kegiatan usaha yang menunjang pembangunan di Indonesia adalah sektor pertambangan. Usaha pertambangan merupakan kegiatan untuk mengoptimalkan pemanfaatan sumber daya alam tambang atau bahan galian yang terdapat dalam bumi Indonesia. Pertambangan adalah sebagian atau seluruh tahapan kegiatan dalam rangka penelitian, pengelolaan dan pengusahaan mineral atau batubara yang meliputi penyelidikan umum, eksplorasi, studi kelayakan, konstruksi, penambangan, pengolahan dan pemurnian, pengangkutan dan penjualan, serta kegiatan pasca tambang.

Setiap pengelolaan pemanfaatan sumberdaya alam tidak dapat dipisahkan dari dampak yang bisa saja terjadi kepada ligkungan hidup dan masyarakat daerah kabupaten/kota. Karena, Masyarakat dan Pemerintah Daerah Kabupaten/Kota yang paling mengetahui situasi dan kondisi yang terjadi pada daerahnya. Mengenai manfaat atau dampak negatif yang mungkin timbul akibat urusan pemerintahan pilihan, termasuk didalamnya mengenai energi dan sumber daya mineral, pemerintah daerah kabupaten/kota diberikan kewenangan untuk menyelesaikan konflik. Akan tetapi, dalam hal ikut serta menentukan apakan Izin Usaha Pertambangan (IUP) dan Izin Pertambangan Rakyat (IPR) dapat diterbitkan atau tidak, pemerintah kabupaten/kota tidak memiliki kewenangan penerbitan izin pertambangan. Secara ringkas, menurut UU No. 23 Tahun 2014 tentang Pemerintahan Daerah, pemerintah kabupaten/kota diabaikan. Dengan demikian Pemerintah daerah tidak memiliki 
otoritas sebagai pelarang dan melakukan tindakan melindungi lingkungan akibat tambang.

\section{B. METODE PENELITIAN}

Penelitian ini dilaksanakan di Kabupaten Trenggalek dengan lokasi pengambilan data Dinas Koperasi, Industri, Perdagangan, Pertambangan dan Energi Kabupaten Trenggalek, Jl. Raya Buluagung Nomor 8 Trenggalek, Jawa Timur. Adapun alasan pemilihan lokasi ini, karena Dinas Dinas Koperasi, Industri, Perdagangan, Pertambangan dan Energi Kabupaten Trenggalek sebagai organisasi pelaksana kebijakan dari pusat dan organi sasi pelaksana pertambangan di daerah.

Penelitian dilakukan dalam beberapa tahapan, yaitu (1) persiapan, (2) pengumpulan data, (3) analisis data, dan (4) penyusunan rekomendasi.

Dalam tahap persiapan disusun siapa saja nara sumber yang akan diwawancarai dan menyusun bverbahgai macam pertanyaan yang akan diajukan kepada beberapa narasumber sebagai sumber data.. pertanyaan wawancara disusun untuk mendapatkan data (1) kebijakan pertambangan di daerah maupun pertambangan di daerah dan (2) persepsi pihak-pihak yang berperan (stakeholders) tentang konsep kebijakan pertambangan di kabupaten trenggalek. Data dikumpulkan dengan metode survei langsung, melalui observasi lapangan dan wawancara, serta studi pustaka. Studi ini menggunakan beberapa metode- analisis: (1) analisis data umum dan potensi agrowisata, (2) Dalam penelitian ini, peneliti akan menggunakan teknik analisis data metode linier dan hirarkis, yang dibangun dari bawah ke atas, tetapi dalam prakteknya pendekatan ini lebih interaktif, beragam tahap saling berhubungan dan tidak harus selalu sesuai dengan susunan yang telah disajikan.

Dengan demikian, informan ditentukan dengan teknik snowball sampling, yakni proses penentuan informan berdasarkan informan sebelumnya tanpa menentukan jumlahnya secara pasti dengan menggali informasi terkait topik penelitian yang diperlukan. Pencarian informan akan dihentikan setelah informasi penelitian dianggap sudah memadai.

Adapun kriteria-kriteria penentuan Informan Kunci (key informan) yang tepat, dalam pemberian informasi dan data yang tepat dan akurat adalah sebagai berikut : a. Kepala Dinas Koperasi, Industri, Perdagangan, Pertambangan dan Energi Kabupaten Trenggalek;

b. Kepala Bidang Pertambangan dan Energi pada Dinas Koperasi, Industri, Perdagangan, Pertambangan dan Energi Kabupaten Trenggalek;

c. Kepala Seksi Pertambangan Umum pada Dinas Koperasi, Industri, Perdagangan, Pertambangan dan Energi Kabupaten Trenggalek;

d. Kepala Seksi Pengendalian dan Reklamasi pada Dinas Koperasi, Industri, Perdagangan, Pertambangan dan Energi Kabupaten Trenggalek;

e.Beberapa Staf Bidang Pertambangan dan Energi pada Dinas Koperasi, Industri, Perdagangan, Pertambangan dan Energi Kabupaten Trenggalek;

Dalam penelitian kualitatif, data diperoleh dari berbagai sumber, dengan menggunakan teknik pengumpulan data yang bermacammacam (trianggulasi) dan dilakukan secara terusmenerus sampai datanya jenuh. Dengan pengamatan yang terus-menerus tersebut mengakibatkan variasi data tinggi sekali.

Dalam penelitian ini, peneliti akan menggunakan teknik analisis data metode linier dan hirarkis, yang dibangun dari bawah ke atas, tetapi dalam prakteknya pendekatan ini lebih interaktif, beragam tahap saling berhubungan dan tidak harus selalu sesuai dengan susunan yang telah disajikan sebagaimana yang telah dikembangkan oleh Cresswel (2010:276-283).

\section{PEMBAHASAN}

Fungsi Pemerintah Daerah Dalam Pengelolaan Pertambangan di Kabupaten Trenggalek

Pertambangan merupakan kegiatan yang sangat dibutuhkan diberbagai sector kehidupan karena peranannya dalam menyediakan komoditas yang berdaya guna baik dalam pembanguan fisik maupun dibidang perekonomian suatu daerah. Keberadaan mineral baik yang merupakan bahan galian merupakan berkah tersendiri bagi setiap daerah karena secara langsung mempengaruhi pendapatan asli suatu daerah, tak terkecuali bahan galian batuan yang juga sangat berperan penting pada sector pembangunan baik berupa infrastruktur umum maupun fasilitas penunjang yang sifatnya personal.

Menurut Kepala Dinas Koperindagtamben Kabupaten Trenggalek dalam 
wawancara pada tanggal 24 Oktober 2016 menerangkan bahwa :

"Pertambangan erat kaitannya denganWilayah Pertambangan dan merupakan bagian dari tata ruang nasional serta merupakan landasan bagi penetapan kegiatan pertambangan."

Wilayah Usaha Pertambangan (WUP) terdiri atas: a. Wilayah Usaha Pertambangan (WUP); b. Wilayah Pertambangan Rakyat (WPR); dan c. Wilayah Pencadangan Negara (WPN)".

Hak dan Kewajiban dibidang Pertambangan. Kewajiban Pemerintah Daerah dibidang pertambangan yaitu melakukan pembinaan dibidang pengusahaan, teknologi pertambangan, serta permodalan dan pemasaran. Pemerintah Daerah Kab.Trenggalek dalam hal ini memiliki tanggung jawab dalam pengawasan dibidang pertambangan untuk menjamin terlaksananya usaha pertambangan sesuai dengan kaidah pertambangan yang baik dan selaras dengan peraturan perundang- undangan yang berlaku.

Pemerintah Daerah juga bertanggung jawab terhadap pengamanan teknis pada usaha pertambangan rakyat yang meliputi: a.keselamatan dan kesehatan kerja; b.pengelolaan lingkungan hidup; dan c.pasca tambang. Pemerintah daerah juga bertanggung jawab dibidang pengamanan teknis dengan mengangkat pejabat fungsional inspektur tambang.

Dalam wawancara dengan Pelaksana Inspeksi Tambang Diskoperindagtamben pada tanggal 1 Nopember 2016 menyatakan :

“Inspektur tambang atau dapat juga disebut Pelaksana Inspeksi Tambang (PIT) memiliki tugas dalam melakukan inspeksi, pengujian, penelahaan proses dan gejala berbagai aspek tambang, mengembangkan metode dan teknik inspeksi, melaporkan dan menyebar luaskan hasil inspeksi".

Pelaksana inspeksi tambang dalam melaksanakan tugasnya memiliki fungsi dalam melakukan pemeriksaan/inspeksi, penyelidikan kecelakaan tambang dan/atau kejadian berbahaya, penyelidikan terhadap pencemaran dan/atau perusakan lingkungan, pengujian atas peralatan tambang pengujian terhadap lingkungan tempat kerja, pengujian terhadap kondisi limbah cair, padat, maupun gas, pembinaan keselamatan dan kesehatan kerja, pembinaan lingkungan pada kegiatan usaha pertambangan umum, memberikan perintah, larangan dan petunjuk baik yang dicatat dalam buku tambang maupun secara lisan, menyusun laporan tertulis mengenai hasil pemeriksaan, membuat berita acara penyelidikan kecelakaan tambang dan/atau kejadian berbahaya, pencemaran lingkungan dan pelanggaran ketentuan-ketentuan dalam peraturan perundang-undangan keselamatan dan kesehatan kerja serta lingkungan pertambangan umum yang berlaku.

Didalam kebun Dilem Wilis terdapat 2 (dua) sungai besar yang mengalir yaitu sungai Sumberwangi yang terletak disebelah Barat Kebun mengalir dari utara ke selatan dengan sumber mata air utama berada di Gunung Bonoero dan sungai Pacet yang berada di sebelah Timur dan juga mengalir dari utara ke selatan. Sungai tersebut merupakan pertemuan aliran mata air dari Gunung Sangku dan mata air yang banyak terdapat di Gunung Pengkol. Selanjutnya sungai ini bertemu dengan aliran mata air dari kebun Dilem Wilis dan mengalir diantara Desa Dompyong dan Desa Botoputih. Aliran inilah yang dipergunakan untuk mengoperasikan pabrik kopi yang berada di perkebunan Dilem Wilis. Sedangkan untuk mata air, terdapat satu mata air yang terdapat di kebun Dilem Wilis yakni mata air pengkol.

\section{Fungsi Pemerintah Daerah Dalam Pengelolaan Pertambangan di Kabupaten Trenggalek}

Pertambangan merupakan kegiatan yang sangat dibutuhkan diberbagai sector kehidupan karena peranannya dalam menyediakan komoditas yang berdaya guna baik dalam pembanguan fisik maupun dibidang perekonomian suatu daerah. Keberadaan mineral baik yang merupakan bahan galian merupakan berkah tersendiri bagi setiap daerah karena secara langsung mempengaruhi pendapatan asli suatu daerah, tak terkecuali bahan galian batuan yang juga sangat berperan penting pada sector pembangunan baik berupa infrastruktur umum maupun fasilitas penunjang yang sifatnya personal.

\section{Menurut Kepala Dinas} Koperindagtamben Kabupaten Trenggalek dalam wawancara pada tanggal 24 Oktober 2016 menerangkan bahwa:

"Pertambangan erat kaitannya denganWilayah Pertambangan dan merupakan bagian dari tata ruang nasional serta merupakan landasan bagi penetapan kegiatan pertambangan." 
Wilayah Usaha Pertambangan (WUP) terdiri atas: a. Wilayah Usaha Pertambangan (WUP); b. Wilayah Pertambangan Rakyat (WPR); dan c. Wilayah Pencadangan Negara (WPN)". Hak dan Kewajiban dibidang Pertambangan

Kewajiban Pemerintah Daerah dibidang pertambangan yaitu melakukan pembinaan dibidang pengusahaan, teknologi pertambangan, serta permodalan dan pemasaran. Pemerintah Daerah Kab.Trenggalek dalam hal ini memiliki tanggung jawab dalam pengawasan dibidang pertambangan untuk menjamin terlaksananya usaha pertambangan sesuai dengan kaidah pertambangan yang baik dan selaras dengan peraturan perundang- undangan yang berlaku.

Pemerintah Daerah juga bertanggung jawab terhadap pengamanan teknis pada usaha pertambangan rakyat yang meliputi: a.keselamatan dan kesehatan kerja; b.pengelolaan lingkungan hidup; dan c.pasca tambang. Pemerintah daerah juga bertanggung jawab dibidang pengamanan teknis dengan mengangkat pejabat fungsional inspektur tambang.

Dalam wawancara dengan Pelaksana Inspeksi Tambang Diskoperindagtamben pada tanggal 1 Nopember 2016 menyatakan :

"Inspektur tambang atau dapat juga disebut Pelaksana Inspeksi Tambang (PIT) memiliki tugas dalam melakukan inspeksi, pengujian, penelahaan proses dan gejala berbagai aspek tambang, mengembangkan metode dan teknik inspeksi, melaporkan dan menyebar luaskan hasil inspeksi".

Pelaksana inspeksi tambang dalam melaksanakan tugasnya memiliki fungsi dalam melakukan pemeriksaan/inspeksi, penyelidikan kecelakaan tambang dan/atau kejadian berbahaya, penyelidikan terhadap pencemaran dan/atau perusakan lingkungan, pengujian atas peralatan tambang pengujian terhadap lingkungan tempat kerja, pengujian terhadap kondisi limbah cair, padat, maupun gas, pembinaan keselamatan dan kesehatan kerja, pembinaan lingkungan pada kegiatan usaha pertambangan umum, memberikan perintah, larangan dan petunjuk baik yang dicatat dalam buku tambang maupun secara lisan, menyusun laporan tertulis mengenai hasil pemeriksaan, membuat berita acara penyelidikan kecelakaan tambang dan/atau kejadian berbahaya, pencemaran lingkungan dan pelanggaran ketentuan-ketentuan dalam peraturan perundang-undangan keselamatan dan kesehatan kerja serta lingkungan pertambangan umum yang berlaku.

Didalam kebun Dilem Wilis terdapat 2 (dua) sungai besar yang mengalir yaitu sungai Sumberwangi yang terletak disebelah Barat Kebun mengalir dari utara ke selatan dengan sumber mata air utama berada di Gunung Bonoero dan sungai Pacet yang berada di sebelah Timur dan juga mengalir dari utara ke selatan. Sungai tersebut merupakan pertemuan aliran mata air dari Gunung Sangku dan mata air yang banyak terdapat di Gunung Pengkol. Selanjutnya sungai ini bertemu dengan aliran mata air dari kebun Dilem Wilis dan mengalir diantara Desa Dompyong dan Desa Botoputih. Aliran inilah yang dipergunakan untuk mengoperasikan pabrik kopi yang berada di perkebunan Dilem Wilis. Sedangkan untuk mata air, terdapat satu mata air yang terdapat di kebun Dilem Wilis yakni mata air pengkol.

\section{E. KESIMPULAN DAN REKOMENDASI}

Upaya pemerintah Kabupaten Trenggalek dalam Perlindungan dan Pengelolaan Lingkungan Hidup salah satunya berupa pembuatan peraturan daerah yang berbasis lingkungan, sebagaimana yang telah diamanatkan oleh Undang-Undang Nomor 32 Tahun 2009 tentang Perlindungan dan Pengelolaan Lingkungan Hidup yang mengisyaratkan setiap pembuatan peraturan perundang-undangan wajib memperhatikan perlindungan fungsi lingkungan hidup dan prinsip perlindungan serta pengelolaan lingkungan hidup sesuai dengan ketentuan yang diatur dalam Undang-Undang Nomor 32 Tahun 2009 tentang Perlindungan dan Pengelolaan Lingkungan.

Kepala Seksi Pengendalian dan Reklamasi Dinas Koperindagtamben Kabupaten Trenggalek menyampaikan perihal Reklamasi Pasca Tambang pada wawancara tanggal 9 Januari 2017 yaitu:

“Pemegang IUP Eksplorasi wajib melaksanakan reklamasi terhadap lahan terganggu pada kegiatan eksplorasi. Sementara untuk IUP Operasi Produksi wajib melaksanakan reklamasi dan pasca tambang pada lahan terganggu pada kegiatan pertambangan dengan sistem dan metode penambangan terbuka dan penambangan bawah tanah. Pemegang IUP eksplorasi dalam melakukan reklamasi wajib memenuhi prinsip:
1) perlindungan dan pengelolaan lingkungan hidup pertambangan; dan
2) keselamatan dan kesehatan kerja. 
Pemegang IPR bersama dengan Pemerintah Daerah melaksanakan reklamasi dan pasca tambang sesuai dengan rencana reklamasi dan rencana pasca tambang serta melakukan remediasi yakni upaya pemulihan pencemaran lingkungan hidup untuk memperbaiki mutu lingkungan hidup serta melakukan restorasi sebagai upaya pemulihan untuk menjadikan lingkungan hidup atau bagian-bagiannya berfungsi kembali sebagaimana semula.

\section{F. REFERENSI}

DPD RI, Desain Pola Hubungan Kewenangan Kabupaten/Kota dengan Provinsi, Sekertariat Jendral DPD RI, Jakarta, 2011

Farida, Maria. Ilmu Perundang-undangan II, Proses dan Teknik pembentukannya. Yogyakarta: Kanisius, 2007.

Fauzi, Gamawan, Paradigma Kewenangan Daerah yang Efektif dan Efisien, Prisma, Volume 29, 2010;

Gie, Liang. Pertumbuhan Pemerintah Dareah di Negara Republik Indonesia. Jilid 111. Jakarta: Gunung Agung, 1968.

Hadjon, Philipus M., dll. Pengantar Hukum Administrasi Indonesia (introduction to the Indonesia administration law). Yogyakarta: Gajah Mada University Press, 2011.

Indoharto. Usaha Memahami Undang-undang Tentaang Peradilan Tata Usaha Negara. Jakarta: Pustaka Sinar Harapan, 2004.

Inu Kencana Syafiie, Welasari, Ilmu Administrasi, Pustaka Pelajar, Yogyakarta, 2015;

Kasper, W.\& Streit M.E, Institutional Economic : Social order and public policy. Cheltelham, 1998;

Keban, Yeremias, Enam Dimensi Strategi Administrasi Publik : Konsep, Teori dan Isu. Yogyakarta : Gave Media, 2004;

Koesoemahatmadja, RDH. Pengantar ke Arah Sistem Pemerintahan Daerah di Indonesia. Bandung: Binacipta, 1978.

M. Amrah. Aspek-aspek Hukum Otonomi Daerah. Bandung: Alumni, 1978.

MD, Mafhud. Membangun Politik Hukum, Menegakkan Konstitusi. Jakarta: Pustaka LP3ES, 2006.
Manan, Bagir. Hubungan Pusat dan Daerah Menurut Undang Undang Dasar Negara Republik Indonesia Tahun 1945. Jakarta: Pustaka Sinar Harapan, 1994.

- Wewenang Provinsi, Kabupaten Dan Kota Dalam Rangka Otonomi Daerah. Jakarta: Pustaka Sinar Harapan, 2000.

Nurjaya, I Nyoman. Pengelolaan Sumber Daya Alam Perspektif Antropologi Hukum. Jakarta: Prestasi Pustaka Publisher, 2008.

Riant Nugroho, Public Policy(Teori Kebijakan, Analisis Kebijakan, Proses Kebijakan, Perumusan, Implementasi, Evaluasi, Revisi Risk Management dalam Kebijakan Publik, Kebijakan sebagai The Fifth Estate, Metode Penelitian Kebijakan), Gramedia, Jakarta, 2012;

Sugiyono, Metode Penelitian Manajemen, Alfabeta, Bandung, 2015;

Tresna R. Bertamasya ke Taman Ketatanegaraan. Bandung: Dibya, tt.

Peraturan Perundang-undangan

Arsip dan Dokumentasi, 2004, Risalah Rapat Persidangan Panitia Khusus (Pansus) Rancangan Undang-Undang tentang pertambangan Mineral dan Batubara tanggal 20 Mei 2005, Dewan Perwakilan Rakyat Republik Indonesia, Jakarta.

Arsip dan Dokumentasi, 2012, Risalah Rapat Persidangan Panitia Khusus (Pansus) Rancangan Undang-Undang tentang pemerintahan daerah tanggal 2

April 2012, Dewan Perwakilan Rakyat Republik Indonesia, Jakarta.

Undang-Undang Dasar Negara Republik Indonesia Tahun 1945

Undang-Undang Nomor 4 Tahun 2009 tentang Pertambangan Mineral dan Batubara (Lembaran Negara Republik Indonesia Tahun 2009 Nomor 4, Tambahan Lembaran Negara Republik Indonesia Nomor 4959);

Undang-Undang No. 23 Tahun 2014 Tentang Pemerintahan Daerah (Lembaran Negara Republik Indonesia Tahun 2014 Nomor 244, Tambahan Lembaran Negara Republik Indonesia Nomor 5587) 


\section{MEDIA505IAN}

Jurnal Ilmu Sosial dan Ilmu Administrasi Negara Vol. 1 No. 2 